\title{
ジエン系ゴムの加硫系について
}

\section{The Vulcanizing System of the Diene Rubber}

Takeshi OHNUKI (Kawaguchi Chemical Industry Corporation, Japan Research and Development Division, 4-6-42, Ryoke, Kawaguchi, Saitama 332-0004, Japan)

Basically, the combination of curing agent, accelerators and sulfur is used as the sulfur curing system of the diene rubber. Also, the accelerator activators, such as zinc oxide or stearic acid, and retarders, are added to the system.

How to use such ingredients governs the control of both processability and physical properties of the rubber products. We explain how to satisfy the various requirements from rubber production by compounding curing agent, accelerators, activators and sulfur, especially for natural rubber compounds.

Key Words : Vulcanizing System, Accelerators, Curing Agent, Retarder, Reversion

1. は じめ め

ジエン系ゴムの硫黄加硫系は，硫黄を始めとする加硫剤 と加硫促進剂の組み合わせを基本とし，酸化亜鉛やステア リン酸等の加硫助剤および加硫遅延剂からなる．それら加 硫に関与する薬品はゴム製品の製造条件や製品そのものに 要求される特性を満たすために，それぞれの薬品の選択と 添加量，併用方法が試行錯誤され，結果加硫系の設計がな される。

その中でも加硫促進剂の併用は重要な要素の一つであ り，例えばMBTS等のベンゾチアゾール類か CBS 等のス ルフェンアミド類を一次加硫促進剂とした場合，二次加硫 促進剂として DPG 等のグアニジン類か TMTD等のチウラ ム類を用いれば何れの選択でも加硫は早くなるが，ゴムの

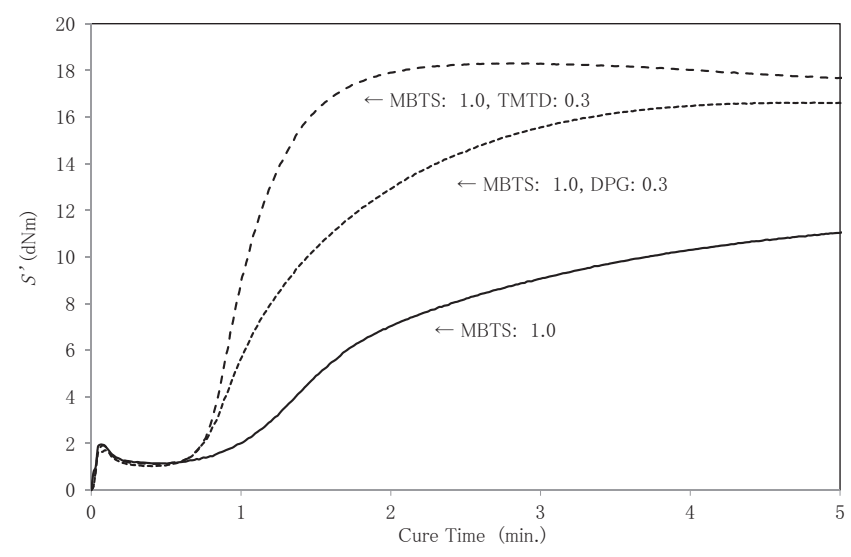

図 1 加硫カーブ・加硫促進剤の併用効果
表 1 加硫ゴム物性・加硫促進剂の併用効果

\begin{tabular}{l|c|c|c}
\hline \multicolumn{1}{r}{ 一次促進剂 } & \multicolumn{3}{|c}{ MBTS : 1.0} \\
\hline 二次促進剤 & なし & DPG : 0.3 & TMTD : 0.3 \\
\hline 硬さ (JIS-A) & 56 & 61 & 63 \\
$200 \%$ 中間応力 (MPa) & 3.3 & 5.0 & 5.3 \\
破断応力 (MPa) & 21.0 & 31.4 & 30.1 \\
破断伸び (\%) & 690 & 740 & 660 \\
耐セット性 (\%), & 67 & 60 & 52 \\
$100^{\circ} \mathrm{C}, 24 \mathrm{hr}$. & & & 5 \\
\hline
\end{tabular}

・図 1, 表 1 の配合 (phr) NR：100、N330 カーボンブラック：40, $\mathrm{ZnO}: 5$, 滑剂 : 2 , ジフェニルアミン系老防 : 2 , 硫黄 : 2 $\cdot 150^{\circ} \mathrm{C}, \mathrm{Tc}(90)$ 加硫

物性面に関してはかなり異なることを図 1 および表1に示 した。この様に加硫促進剤の単純な組み合わせの違いによ ってもゴムの特性が大きく変動する要素が多分に含まれる 加硫系に関して, 要求される幾つかの特性をどの様にすれ ば満たせるのか天然ゴムの配合を以て説明したい。

\section{2. 加硫促進剤の構造と考え方}

ゴムの加硫系を構成する加硫系ゴム薬品は多種であり複 雑に思われるが，加硫系を検討する上でそれらゴム薬品を

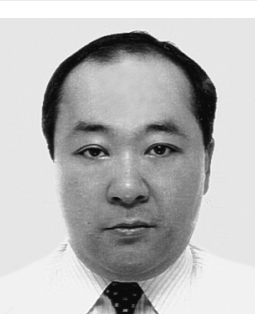

川口化学工業侏研究開発部高分子加工グルー プ（テ332-0004 埼玉県川口市領家 4-6-42）グ ループリーダー。平成 3 年埼玉工業大学工学部 環境工学科卒業，同年，川口化学工業侏入社, 現在に至る. 専門は有機ゴム薬品全般. 
選択することについては特別に難しく考える必要はない. 特に加硫促進剤は体系的に発展してきた経緯もあり，基本 構造を主体に見ることで個々の特性を類推することができ る $^{1)}$. また加硫反応の初期段階（相互反応）, 中期段階 (促進反応), 後期段階（分解と副生）の挙動を加硫試験機 (レオメーター等) で観察しつつデータを集積し，その時 に使用した薬品の化学構造と照らし合わせることで知見を より深めることができる. 次に代表的な加硫促進剤の構造 と特性について説明する.

\section{1 チアゾール類, スルフェンアミド類}

チアゾール類およびスルフェンアミド類の共通構造はメ ルカプトベンゾチアゾール（MBT）である．まず，MBT またはそのアミン塩や金属塩は，官能基であるチオールが 露出した構造であるため反応がし易く低温でも加硫促進性 が得られる反面，配合ゴムの加工安定性や貯蔵安定性を含 めたスコーチ安定性に劣る。一方，MBTのチオールを-SS-結合として二量化したものがMBTSであり，MBT等よ りもスコーチ安定性が改善される. 更に, MBTとアミン が-S-N-結合（スルフェンアミド結合）したスルフェンア ミド類（CBS等）は，加工安定性の確保が最も容易な遅 行性加硫促進剤とも言われる。 また加硫中に特性基である スルフェンアミド結合が分解することにより，MBTと共 に加硫反応を早める塩基性アミンが生成し，単独でも十分 な加硫促進性が得られる利点もある。ただし配合ゴムの䝰 蔵安定性は状況（例えば高温多湿下）にもよるが，あまり 良いとは言えず，改善された物質として一級アミンに MBTが二分子付加したスルフェンイミド体（Santocure TBSI, CAS No.: 3741-80-8) が存在し，チアゾール類の一 つの完成点であると考える ${ }^{2)}$.

\section{2 ジチオカルバミン酸塩類, チウラム類, 他}

ジチオカルバミン酸塩類とチウラム類はジチオカルバミ ン酸を基本構造とする.ジチオカルバミン酸自体は室温に おいても不安定な物質であり，金属やアミンで塩をつくり
安定化（ジチオカルバミン酸塩類）させるか, ジチオカル バミン酸同士を-Sx-結合で二量化（チウラム類）する必要 がある，従って構造自体は異なるものの，類型的にチアゾ ール類と同様な考え方で良く，加硫促進性重視であればジ チオカルバミン酸塩類を選び，スコーチ安定性を得たいの であればチウラム類を選択すればよい。ただし, 硫黄供与 体として用いる場合には，チウラムポリスルフィドを選択 する必要がある。ちなみに日本では普及していないが，遅 行性を有するスルフェンアミド体 (Cure-Rite 18, CAS No.: 57018-26-5）も存在する.

一方，ジチオリン酸類も同様な構造的関係が見られ，ア ミンおよび金属塩物質とポリスルフィドがあり用法的な選 択も同様で良く，ニトロソアミンフリーな加硫促進剤とし ての側面を持つ。更にキサントゲン酸類も同様であるが， 塩類は超促進剤，モノおよびジスルフィド体は促進作用も 硫黄供与体としての作用も弱いが，ポリスルフィド体 （Robac AS100, CAS No.: 137398-54-0）は良好な硫黄供与 体となる.

\section{3 グアニジン類, 他}

グアニジン類は塩基性加硫促進剤であり, 単独で使用す ることは殆どなく二次加硫促進剤として用いられる．類縁 構造としてはチオウレア類が挙げられるが, ジエン系ゴム の加硫系に用いられるのは稀であり，一部EPDM配合や 発泡ゴム系に使用されるに留められている，同様な用法で 用いられる加硫促進剤としてはアルデヒド・アンモニア類 (H等) やアルデヒド・アミン類 (BAA等) がある.

\section{3. 加硫剤および加硫促進剤の併用について}

加硫系を構成する薬品の添加量は, 同じく物性を左右す るフィラー等と比べると少ないながらも大きな影響を与え る. 表 2 に代表的な硫黄加硫系の方式を示した。何れの加 硫方式にも利点と欠点があるが，最近の傾向として欠点が 顕著に表れ難い準有効加硫方式の採用が増えているように

表 2 ジエン系ゴムの加硫方式

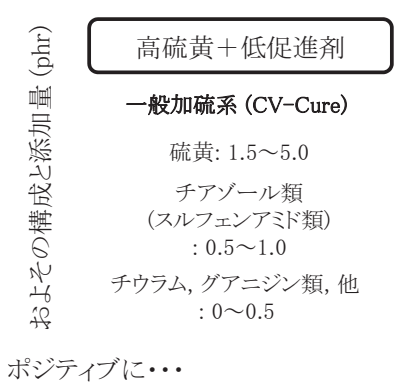

高弾性, 低コスト ネガティブに・..

耐老化性が悪い （物性の変動が大きい）

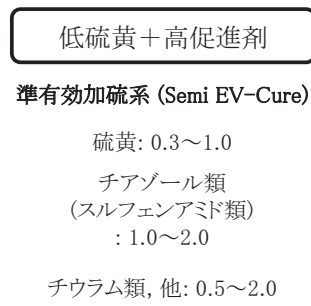

好バランス

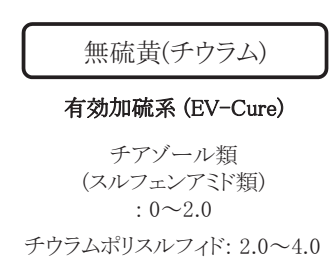

加硫剂(硫黄供与体): $0 \sim 2.0$

低永久丕, 而熱 ブルーミングの危険性 


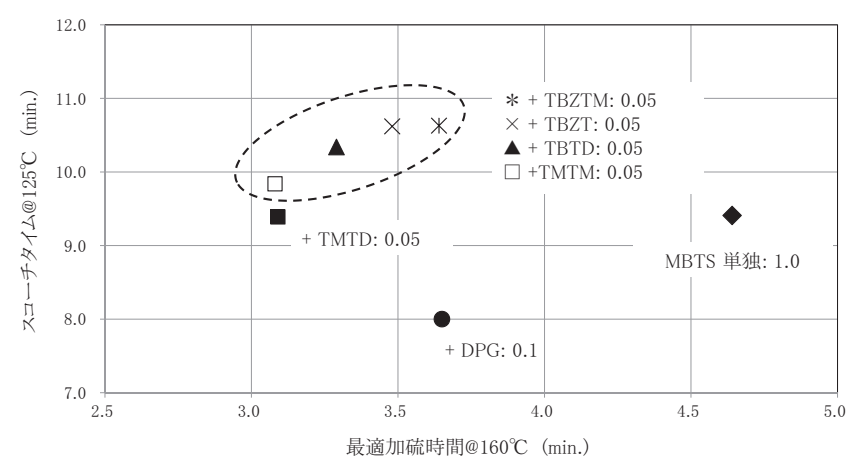

図2 チウラム類の微少併用による加硫遅延効果

•図 2 の配合（phr）NR：100, N330カーボンブラック：40, $\mathrm{ZnO}: 5$, 滑剤 : 2 , ジフェニルアミン系老防 : 2 , 硫黄 : 2.5 , TBZT：ジベンジルチウラムジスルフィド, TBZTM : ジベンジ ルチウラムモノスルフィド

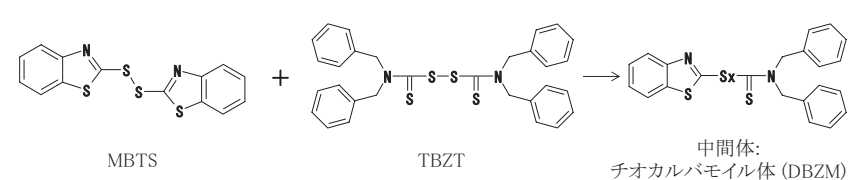

図 3 チアゾール類とチウラム類による中間体

感じる. 準有効加硫方式を構成する加硫促進剤は，チアゾ ール類とチウラム類（ジチオカルバミン酸塩類）を主体に 構成される場合が多く，この二つの物質間に相互作用が存 在することを示唆する幾つかの例を挙げ，その作用が加硫 設計上無視できないことを説明したい.

\section{1 チアゾール類/チウラム類併用による加硫遅延効果}

加硫促進反応の前段階において，加硫剂や加硫促進剂が 化学的に影響を及ぼし合っていることは，間接的にではあ るが加硫曲線の挙動や事後のブルーム物質の分析等から推 測できる．例えば一般的な併用量，併用比においてチアゾ ール類へチウラム類を併用すれば加硫が早くなると共にス コーチ性も高まることが知られている。しかし，図 2 が示 す様に比較的加硫促進力の穏やかなチウラム類（高分子量 もしくはチウラムモノスルフィド）を僅かに併用すると， MBTS 単独添加よりも加硫が早まりつつ，スコーチ性も 安定化する微少添加領域（図中点線で囲まれた部分）が見 出される。このことは，それら促進剤同士が図 3 の如く反 応中間体を一時的に作り，トラップし合うことで促進反応 が抑制されることを示唆しており，むしろ加硫遅延剂が効 き難い準有効加硫系から有効加硫系での加硫調整時に重要 な要素となる.また, 同様な反応例として促進剤とシラン カップリング剂の相互作用について幾つか発表されている ので参考にして頂きたい 3,4$)$.

\section{2 チアゾール類／チウラム類の併用による加硫戻り 抑制効果}

例えば天然ゴムを高温または長時間加硫すると，加硫戻 りが発生することが知られており，昔から技術的な課題と して取り上げられることも多い. 図 4 に典型的な加硫戻り
の例を加硫カーブで示した。最高弾性トルク（最低粘性卜 ルク）を越えた辺りから徐々に弾性トルクの低下と共に粘 性トルクの上昇が見られ，加硫戻りの状態が観測される. 従って加硫戻りが進行するということは，ヒステリシスロ スが増大することを示しており，ゴム製品によっては致命 的な欠点になる.

加硫戻りに対してチアゾール類とチウラム類を基本とす る有効加硫系や準有効加硫系は，耐性を示すことが良く知 られているが，一般加硫系においてもそれらの併用は有効 である。図5はMBTS/TBZT併用時の加硫戻り率を示し たものであり，MBTSもしくはTBZTを単独で用いた場 合よりもそれらを併用すると加硫戻りが小さいことがわか る. 特に MBTS：0.4 部, TBZT：0.6 部の併用量におい て最も戻りが小さい。従って加硫戻りに対しては, 硫黄の 添加量を減じる事は言うまでもなく，チアゾール類とチウ ラム類（ジチオカルバミン酸塩類，ジチオリン酸塩類等で も良い）の併用に効果がみられ，その併用比も影響を与え る.

ちなみにこの $4 ： 6$ の併用比は, 図3で示したチオカル

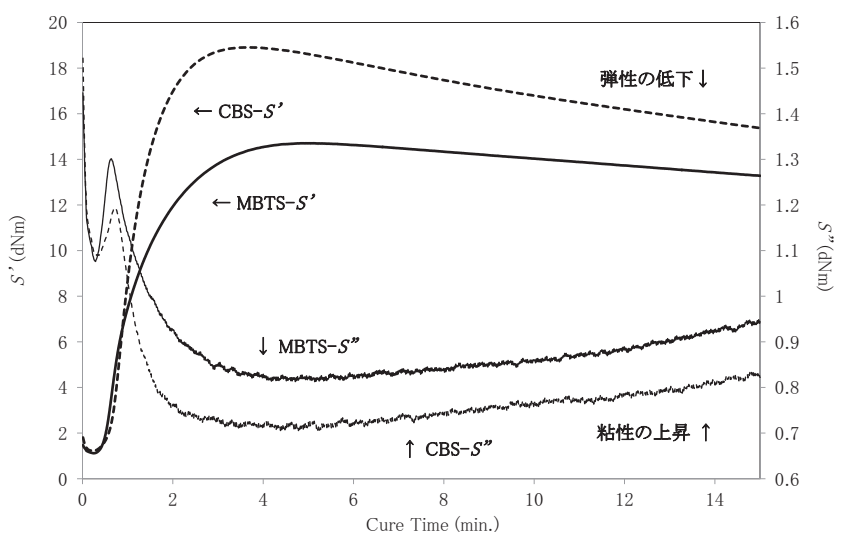

図4 加硫カーブ・加硫戻り挙動

・図4 の配合（phr）NR：100，N330カーボンブラック：40, $\mathrm{ZnO}: 5$, 滑剤 : 2 , ジフェニルアミン系老防 $: 2$, 硫黄 : 2.5 , 促 進剤：1.0

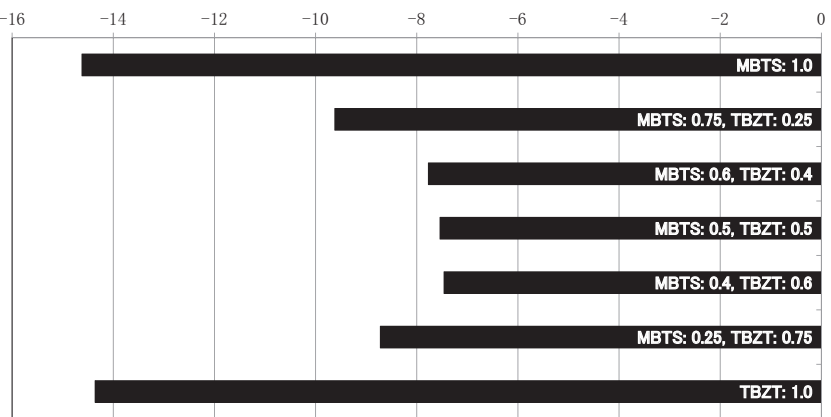

図 5 MBTS/TBZT併用と加硫戻り率

レオメーター測定における最高弾性トルクに対する測定 15 分後の弾 性トルクの変化率を加硫戻り率とした

・図 5 の配合（phr） NR：100, N330カーボンブラック：40, $\mathrm{ZnO} ： 5$, 滑剤：2，ジフェニルアミン系老防：2, 硫黄 $: 2.5$ 
バモイル体のチアゾール/ジチオカルバミン酸の分子量構 成比にほぼ相当するが，このチオカルバモイル体は常温常 圧において安定した化合物（DBZM, CAS No.: 62652-32-8） として取り出せる ${ }^{5)}$. その性能を検証したところ，先の MBTS：0.4部，TBZT：0.6部に対して相当する 1 部の添 加量で耐加硫戻り性は同等となり，静的にも動的にもほぼ 同等なゴム物性が得られた。更にDBZM ならではの特徴 として図6の如く $\mathrm{CBS}$ 並の加硫遅延性を付与されることが 挙げられる。従って，加硫遅延性と耐加硫戻り性を有する DBZM は，両特性が要求される厚物ゴム製品に向くと期 待されるわけであるが，この構造自体は古く，加硫促進剂 として 1920 年代後半 (スルフェンアミド類は 1930 年〜) には発表されていたことを付け加える ${ }^{1)}$.

\section{3 加硫系の実践例}

次に著者が行った加硫系の検討例を幾つか紹介する．検 討の仕方は様々であり結果も同様である。これが唯一の正 解と言うわけでもなく，検討の切り口の参考として頂けれ ばと思う。

図 7 は典型的な一般加硫系を A とし，耐セット性（耐熱 性も）を改善するためのアプローチを示したものである. 改善された加硫系は加硫速度とスコーチ安定性およびゴム 硬度など一般的な加硫ゴム物性が A と同等であることを 条件とする。

まず比較的硫黄添加量の多い準有効加硫系である B1 試し，耐熱，耐セット性が改善されると共に低ヒステリシ スロスであることが特徴であった。ただし，ややスコーチ 安定性に欠け, 加硫遅延剂を併用することも考えられたが, $\mathrm{B} 2$ の如く CBS等のスルフェンアミド類と TBTD等比較的 分子量の高く加硫促進力の穏やかなチウラムジスルフィド 類を用いて対応した。ちなみにTBTDを若干増量するこ とで加硫速度とゴム硬度の調整を行っている。

$\mathrm{C} 1$ は Bの系よりも硫黄の添加量がより少なく，耐熱，

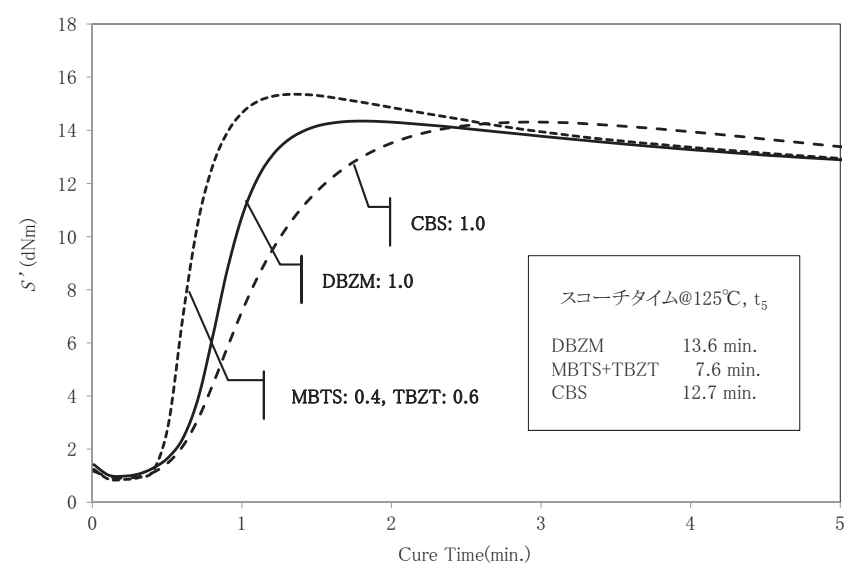

図6 加硫カーブ・DBZM

・図6の配合（phr） NR：100, N330カーボンブラック：40, $\mathrm{ZnO}: 5$, 滑剂 $: 2$, ジフェニルアミン系老防 $: 2$, 硫黄 $: 2.5$
耐セット性が共により改善され，且つスコーチ安定性も良 かった．ただし，TMTDを起因とするブルーミングの恐 れがあるので，C2の如く TMTDをよりブルームし難い TBTDか TMTMへ変更し，加硫ゴム物性補償のため，硫 黄供与体であるジチオジモルホリン（DTDM）を併用し てノンブルーミングとした。物性補償の為チウラム類を増 量せずに敢えてDTDMを用いたのは，加硫遅延性（促進 剂との相互トラップが考えられる)が得られるからである。 準有効加硫系は一般的な加硫遅延剤が効き難い傾向があ り，その場合にも応用することができる。

D1は典型的な無硫黄加硫系（チウラム加硫）であり， 最良の耐セット性と耐熱性が得られるものの，ほほ確実に ブルーミングを伴う。ノンブルーミングを達成するため, 基本線としてD2の加硫系へ考えが及ぶも, 耐セット性が 低下したのでD3の加硫系とした。D 鉛（ZMA）は非硫黄系加硫剤であり，一般的には過酸化 物架橋用の架橋助剤として知られているが, 硫黄加硫系に 適量併用すると耐熱性や耐セット性が改善する．また加硫 反応（弾性，速度）を高めるために敢えて硫黄を少量添加 するので，実質的には準有効加硫系である.

\section{4 準有効加硫系の実践例}

図 8 も典型的な一般加硫系を F とし, 耐熱性を主体に改 善するためのアプローチを示したものである．条件は先ほ どと同様に $\mathrm{F}$ と同等とする。 また，耐熱性だけではなく加 硫戻りも改善したい。ちなみにFはCBSを使用している ため，図7のMBTSを使用したAよりもゴム弾性に富み， ゴム硬度で $10^{\circ}$ 高い。

まず加硫戻りが改善される Gを試し，加硫ゴム物性面で は申し分のない性能を示したが, スコーチ安定性に劣った。 B2やB3の様な準有効加硫系も試し，耐熱面では改善が見 られたもののゴム硬度が低い。DTDMを併用すればゴム 硬度は上がるだろうが，加硫が必要以上に遅くなってしま

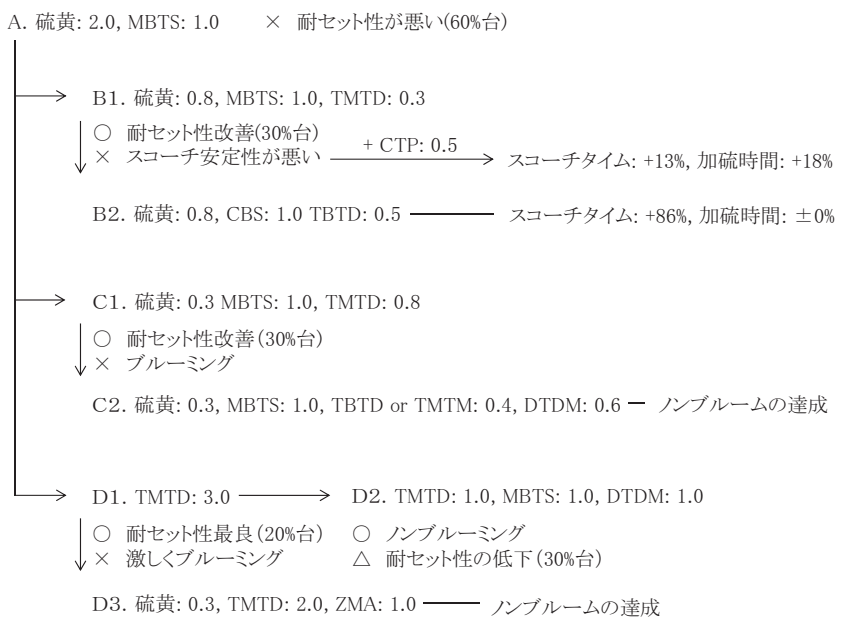

図7 加硫系の実践例・耐セット性の改善

・図 7 の配合（phr）NR：100，N330カーボンブラック：40, $\mathrm{ZnO} ： 5$, 滑剂： 2 , ジフェニルアミン系老防：2 
j.

よってここは敢えて B 2 と B 3 の中間的な組み合わせと し，チウラム類（TBZT）を多く添加する B4とした。結 果を図 9 に示す.

見るべき点はB4の適正加硫（Tc90） と長時間加硫（30 分）の物性の変動が $\mathrm{F}$ と比べて小さいことにある。それは 安定した架橋形態のみでもたらされているわけではなく， 物性の変動要因となる加硫系薬品の未反応物や加硫残渣物 質が少ない（不活性化している）ことも要素として考えら れる。また，俗に言う平坦加硫の重要さが説かれた結果で もある。

\section{4. 硫黄加硫に併用される加硫剤}

硫黄と加硫促進剂の組み合わせでは，モノ〜ポリスルフ イド構造の形態で架橋され, それらの比率と密度および分 布で物性が決定されるが，それ以上の性能や機能を付与す る場合には非硫黄架橋剤を併用して混成架橋させる方法が とられる6).

\section{1 ビスマレイミド}

剛直で熱安定性に優れた構造であり，耐セット性や耐熱 性を付与することができる．硫黄加硫との併用では反応性 が高いとは言い難く，高温加硫（170 ${ }^{\circ} \mathrm{C}$ 以上）を行い，架 橋反応を完結させる必要がある。その場合，MBTSは反 応触媒（酸化剂）となる。

\section{2 ビスシトラコンイミド}

ビスマレイミドの両端にアルキル基が付加された構造. 架橋反応はビスマレイミドよりも緩やかであり，特に天然 ゴムベースの大型ゴム製品，即ち長時間加硫を行う際には 加硫戻り防止剤として高い効果を示す。また，加硫戻り防 止剂についてはその他にも数々の物質が試されている7).
F. 硫黄: 2.5, CBS: 1.0 ゴム硬度: $65^{\circ} \rightarrow$ 而熱性を改善したい

G. 硫黄: 2.5 MBTS: 0.4, TBZT: 1.0

○ゴム硬度が高い(ゴム硬度: $70^{\circ}$

○加硫戻りの改善

$\triangle$ 耐熱性やや改善

×スコーチ安定性に劣る

B2. 硫黄: 0.8, CBS: 1.0, TBTD: 0.5

B3. 硫黄: 0.8, MBTS: 1.0, TBZT: 0.5

○耐熱性の改善

×ゴム硬度が低い(ゴム硬度: $55^{\circ}$ )

B4. 硫黄: 0.7, CBS: 1.0, TBZT: 3.0

図8 加硫系の実践例・耐熱性の改善

・図 8，9の配合（phr） NR：100, N330カーボンブラック：50, $\mathrm{ZnO}: 5$, 滑剂 : 2 , ジフェニルアミン系老防 : 2

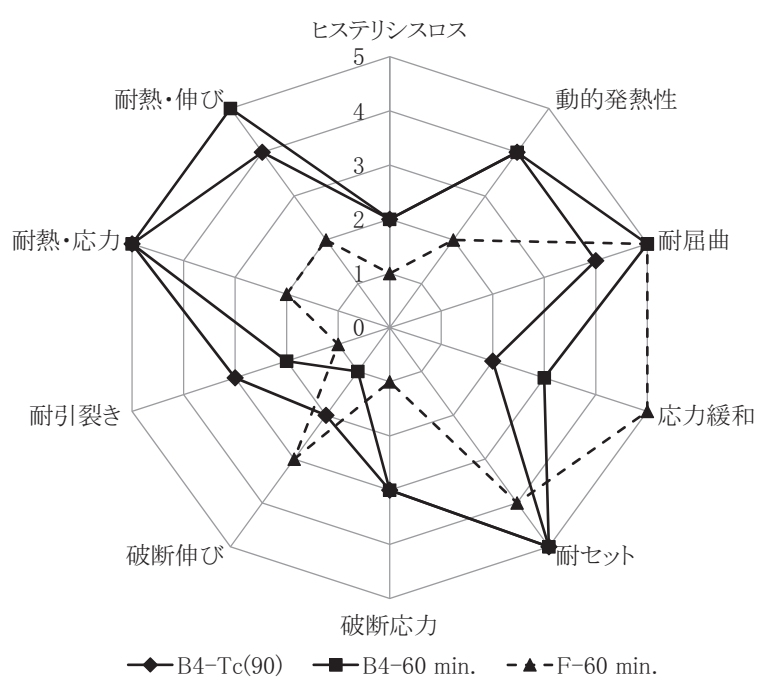

・ 一般加硫系 $(\mathrm{F})$ の適正加硫を 3 点 (平均) とした ・点数が高いほど優れるとした

・ヒステリシスロス低いことを良いとした

・応力緩和は小さい(遅い)ことを良いとした

図9 加硫系の実践例・耐熱性の改善（特性比較）<smiles></smiles>

ビスマレイミド

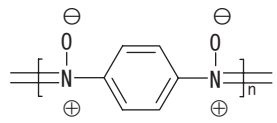

ポリ-p-ニトロソベンゼン<smiles>CC1=CC(=O)N(PN2C(=O)C=C(C)C2=O)C1=O</smiles>

ビスシトラコンイミ゙

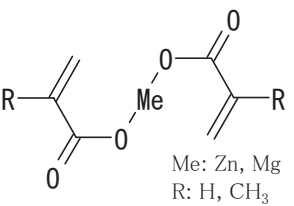

アクリル,メタクリル酸金属塩

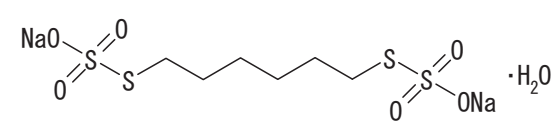

A1 (Duralink HTS) CAS No.: 5719-73-3<smiles>S=C(SSCCCCCCSSC(=S)N1Cc2ccccc2-c2ccccc21)N(Cc1ccccc1)Cc1ccccc1</smiles>
CAS No.: $151900-44-6$<smiles>CC(C)(C)CCOCCOCCC(C)(C)C</smiles>

B1 (2OSx Polymer)

図 10 硫黄加硫系に併用される加硫剂 


\section{3 アクリル酸, メタクリル酸金属塩}

亜鉛塩やマグネシウム塩が一般的に用いられる。耐熱性 を付与し特に伸びの低下を抑える効果が大きい。 また金属 イオン架橋の形態をとるので架橋間のズレが生じることを 応用すれば，ゴムの動倍率へ影響を与えることもできると 考える. アイオノマーと言う高分子があるが，その高分子 の特性をイメージさせる.

\section{4 ポリ-p-ニトロソベンゼン}

一般的にはブチルゴム用のコールドフロー防止および物 性向上殽（応力向上）として用いる。 あまり知られていな いが，ジエン系ゴムに対しても作用する．極めて反応性が 高いので動的部分架橋への応用が期待される.

\section{5 耐熱性と柔軟性を付与する架橋剤}

A 1 および A 2 は熱安定性と架橋鎖の柔軟性に優れたへ キサメチレンジチオール (-S- $\mathrm{CH}_{2}-\mathrm{CH}_{2}-\mathrm{CH}_{2}-\mathrm{CH}_{2}-\mathrm{CH}_{2}-\mathrm{CH}_{2}-$ S-）でゴムを架橋し，硫黄加硫では相反する特性である耐 熱性とヒステリシスロスの低減が両立できる．A1は反応 性を高めるためにチウラム類かジチオカルバミン酸塩類を 併用すると良く，A2 は構造中にジチオカルバミン酸構造 を有するので単体でも反応性が高く促進剤としても作用す る.一方, B1はジオキサオクタンジチオール (-S-CH $\mathrm{CH}_{2-}$ $\left.\mathrm{CH}_{2}-\mathrm{O}-\mathrm{CH}_{2}-\mathrm{CH}_{2}-\mathrm{O}-\mathrm{CH}_{2}-\mathrm{CH}_{2}-\mathrm{S}-\right)$ でゴムを架橋する。へキ サメチレンジチオール架橋と同様に熱安定性と架橋鎖の柔 軟性に優れ，同様な特性をゴムに付与することができる. $\mathrm{x}$ が 3 以上の場合は硫黄供与体としても作用するが加硫促 進性は無いので促進剤を必要とし, チウラム類かジチオカ
ルバミン酸塩類を用いると良い。ちなみに有効加硫系も組 め, 耐熱性と動的特性に優れたゴムが得られる反面, 柔軟 な架橋故に耐セット性はあまり良くない.

\section{5. 終わりに}

加硫系を試行錯誤し設計することは，配合と同様にゴム 製品に課される数々の制約を満たす手段として有効であ る.それは先人の組み上げた加硫系と検討の経緯を見れば 理解できると思う。さじ加減一つでゴムの物性が変化する 加硫系をいじることは緊張を伴うが，楽しいことでもある と感じて欲しい。

\section{References}

1) Watanabe, T.; Ohara, M.: Nippon Gomu Kyokaishi, 56, 678 (1983)

2 ) Datta, R. N.; de Hoog, A, J.: Kautschuk Gummi Kunstsoffe, 54, 256 (2001)

3 ) Datta, R. N.; Das, P. K.; Mandel, S. K.: Kautschuk Gummi Kunstsoffe, 41, 157 (1988)

4 ) Swapan, K. M.; Dipak, K. B.: Rubber Chemistry and Technology, 67, $672(1994)$

5 ) Ohnuki, T.; Yano, D.: Jpn. Kokai Tokkyo Koho 2007-327020 (2007)

6 ) Hirata, Y.: Polymer Digest, 45 (11) , 28 (1993)

7 ) Kenneth, B.: Rubber World, 249, 27 (2013)

\section{日本語表記参考文献}

1 ）渡辺隆，大原正樹：日本ゴム協会誌，56，678（1983）

5 ）大貫毅，矢野大吾：特開 2007-327020（2007）

6 ）平田靖：ポリマーダイジェスト, 45 (11), 28 (1993) 